\title{
METHODICAL PROBLEM IN THE RESEARCHES OF EDUCATIONAL HISTORY
}

\author{
Hüseyin ŞİMŞEK ${ }^{*}$
}

\begin{abstract}
The main aim of this study is to attract attention to the methodical problem in research of educational history. Method, is a way that must be pursued for scientific researches. Educational researches which are the sub-field of history researches, are considered in the qualitative part of researches. Study comes into being from two main part. The first part includes theoretical knowledges related to the researches of history and educational history and the second part includes a conceptual framework related to qualitative method which is used in the researches of educational researches.
\end{abstract}

Key Words:Educational History, Educational Research, Qualitative Research

\footnotetext{
* Assist. Prof. Dr., Harran University, Faculty of Educatioan, Department of Educational Sciences, e-mail: husimsek@hotmail.com
} 


\section{SUMMARY}

Educational history can be itentified as the instruction and the education history of an nation in general. In other words, educational history is a subfield of general history and a history science which is connected with education. Since the life-long instruction and education is in everywhere where the human being and soceity is there, educational history is an old science as old as mankind history. Educational history reseaches which are developed as a branch of General History researches closely connected with the aims, functions and the methods of general history reseaches. However, the problematical of which method must be used in educational history researches, at the seme time constitutes the main methodical problem of this study. Educational history studies are considered in the context of qualitative researches. Qulitative researches tend to focus on written and visual materials of the research problem where the cases of direct observetion and interview is not possible. Qualitative researches in its nature tried to point out the reciprocal interactions, flexibility and relations among diverse stages of research process. That is why, the extend and the method of educational researches is a fundamental problem which must be dwelled upon. In this extend, the processes of sample selection, data gathering technique and the data analysis are the basic processes that must be pursued for Educational History researches. 


\title{
EĞİTIM TARIHİ ARAŞTIRMALARINDA YÖNTEM SORUNU
}

\author{
Hüseyin ŞİMŞEK ${ }^{* *}$
}

Öz.Bu araştırmanın temel amacı, Eğitim tarihi araştırmalarına ilişkin yöntem sorununa dikkat çekmektir. Yöntem, bilimsel araştırmalar için izlenmesi gereken yoldur. Sosyal bilimler araştırmaları arasında yer alan ve Tarih araştırmalarının bir alt dalı olarak kabul edilen Eğitim Tarihi araştırmaları bir başka yönüyle nitel araştırmalar kısmında değerlendirilmektedir. Araştıra iki ana kısımdan oluşmaktadır. Birincisi Tarih ve Eğitim Tarihi araştırmalarına ilişkin kuramsal bilgiler, ikinci kısımda ise Eğitim tarihi araştırmalarında kullanılabilecek nitel yönteme ve eğitim tarihi araştırmalarının temel kaynaklarına ilişkin bilgiler yer almaktadır.

Anahtar Kelimeler: Eğitim Bilimi, Eğitim Tarihi, Nitel araştırmalar.

\footnotetext{
** Yrd.Doç.Dr., Harran Üniversitesi, Eğitim Fakültesi, Eğitim Bilimleri Bölümü, e-mail: husimsek@hotmail.com
} 


\section{GİRIŞ}

Eğitim araştırmaları, bilimsel kuramları test eden, ampirik ve analitik ilişkileri saptayan ve eğitsel uygulamaların değerini ortaya koyan disiplinler arası araştırmalardır (Balc1:1997:18). Bu yüzden eğitsel araştırmalar yöntem ve tekniklerini orijinal olarak geliştirilen bilim dallarından almış; ancak onların bazılarını olduğu gibi kullanmış, bazılarını ise eğitim ortamına uygularken değişme uğratmıştır.

Eğitim Bilimi araştırmaları içerisinde önemli bir yere sahip olan Eğitim Tarihi aslında genel Tarih araştırmaları içerisinde yer alan eğitimle ilgili bir Tarih bilimidir (Akyüz:2007:1). Eğitim tarihi araştırmaları genelde tarih araştırmalarının bir kolu biçiminde gelişmiştir. Bu nedenle öncelikle tarih ve tarih araştırmaları hakkında özet bilgiye yer verilecektir.

\section{Tarih Bilimi ve Tarih Araştırmalarında Yöntem Sorunu}

Tarih bilimi hakkında çeşitli tanımlamalar yapılmaktadır. Ariell ve Durant'ın "Geçmişte olan hadiseler hakkındaki belgelerin verileri" (Kütükoğlu:1998:1) biçimindeki tarifine karşın, E.H.Carr, tarih için "Geçmişle günümüz arasında bitmeyen diyalog" (Kütükoğlu:1998:2) tanımlamasını yapar. Bir başka tarihçi ise "Tarih, kollektif bellektir, insanların kendi toplumsal kimlik kavramlarını ve geleceğe ilişkin beklentilerini oluşturmalarını sağlayan deneyimlerin toplamıdır" (Tosh:1997:3) der.

Tarih araştırmalarının temel konuları dört ana başlık altında mütalaa edilebilir. Bunlar siyaset tarihi, düşünce tarihi, iktisat tarihi ve sosyal tarih alanlarıdır. Bu genel alanlar içerisinde dönem, ulus, olay, kurum ve şahıslar üzerine de birçok tarih araştırması yapıla gelmiştir.

Tarihin gerekliliğine dair bazı görüşler ileri sürülmüştür. Buna göre tarih bilgisini zorunlu kılan en önemli etken, toplumların geçmişlerine dair merakıdır. Tarihin gerekliliği ve yararları üzerinde duran tarihselcilik akımı (Historismus), bugünün kültür ve kurumlarını anlamanın, ancak tarihselci bakışla mümkün olabileceğini savunur. Tarihselciler daha da ileri giderek "Dünyayı kavramanın püf noktası akal değil tarihti” (Tosh:1997:14) derler.

Tarihin rolü ve işlevi hakkında da birkaç cümle söylemek gerekirse, öncelikle tarihin toplumsal rolüne işaret etmek kaçınılmazdır. Çünkü toplumların kullanabilecekleri bir geçmişe ihtiyaçları vardır ve toplumsal düzene ilişkin farklı arayışlar sürmektedir. $\mathrm{Bu}$ arayışlar farklı tarihleri yaratmakta, birçok tarihçi de bunlardan birinin yanında yer almaktadır. 
Burada şu temel soru akla gelmektedir: "Tarih, ancak (ne kadar saygı değer olursa olsun) bir ideolojiyi desteklemek üzere kullanılabilecek bir şey mi? Yoksa bağımsız bir bilgi dalı olarak kendi başına değer taşıyor mu ?" (Tosh:1997:12). Bu ve benzeri sorular önemli bir tartışmayı beraberinde getirir, ancak konumuzla ilgisi olmadığından, bu tartışmalara burada yer verilmeyecektir.

Tarih araştırmalarında dikkat edilmesi gereken bazı noktalar bulunmaktadır. Her şeyden önce tarih araştırmaları, esaslı bir tarih bilinciyle sürdürülmelidir. Ünlü tarihçi Ranke, tarih bilincinin nasıl kazanılacağını şu iki ilkeyle açıklar: Öncelikle araştırmacı bütün önceki çağlar ile kendi çağı arasında bir uçurum yaratan ortam ve zihniyet farklılıklarını kavramalıdır. Daha sonra da yaşanan anın kendine özgü karakterinin geçmişteki o ortam ve zihniyetten bugüne nasıl gelindiğine bağlı olduğunu anlamak gerekir (Tosh:1997:16). Bu ilkeler aynı zamanda akademik tarih araştırmalarının da mihenk taşını oluşturur. Tarih araştırmalarına bu perspektiften bakılabilirse anakronizm tehlikesi de ortadan kalkmış olur.

Tarih araştırmalarında bilinmesi gereken bir diğer unsur da tarihin konusunun ne olduğudur. Kütükoğlu'na göre tarih, “... İnsanların düşüncelerinin ifadesi olan ve zamanla ortaya çıkan olayları, insanların yönlendirdiği sosyal gelenekleri konu edinir." (Kütükoğlu:1998:2). Bu nedenle tarih, bütün bu olayları şekillendiren kanunları bulmayı, gelişme ve çöküş, tekâmül ve yozlaşmanın koşullarını ve safhalarını açıklığa kavuşturmayı amaçlar.

Diğer yandan tarihin, insan ürünü olan bir geçmişi incelediğinin unutulmamas1 gerekir. Tarihi yapan insanların, farklı ruh yapılarına sahip olmaları nedeniyle, tarihi olayların meydana gelmesinde, bu ruh yapilarının rolleri hesaba katılmalıdır. Kütükoğlu'nun ifadesiyle “...Tarihçi, sadece fikirlere ilgi duymayı, bu fikirlerin içindeki duygu ve heyecanın köklerine de inmelidir." (Kütükoğlu:1998:3). Bu bağlamda temel sorun, toplumların farklı psikolojilere sahip olmalarının (sosyal güdü) göz önünde bulundurulmasıdır. Tarihsel olayların esaslı biçimde kavranması ancak bu yolla mümkün olabilir.

Tarih araştırmalarında dikkat edilmesi gereken bir diğer önemli sorun ise tarihe bakıştır. Zira tarih araştırmalarının sadece bir perspektiften ele alınması ve bazen belirli bir doktrini meşrulaştırmak amacıyla, dar kalıplara sokulması sıkça yaşanan bir olgudur. Bu nedenle tarihi olayların her birinin genel ve özel koşullar etrafinda geliştiği göz önünde bulundurulmalıdır. Bu ilke, tarih araştırmacılarında bulunması gereken nesnellik sorununa işaret eder. 
Tarih araştırmalarında, araştırmacı tarafından benimsenen tarih felsefesi görüşü, çoğu kere, araştırmaya yön verir. Togan, tarihçilerin benimsediği, teokratik, düalist, materyalist, pozitivist, idealist, ve hümaniteci tarih telakkileri olmak üzere altı ayrı tarih felsefesinden söz eder (Togan:1985:14). Esasen tarih araştırmaları genellikle bu tarih felsefelerinin temel ilkeleri doğrultusunda yapıla gelmiştir. Her birinin farklı ilkeyi temel alarak yürüttüğü araştırmalar, toplumların yaşamını yönlendiren diğer veçheleri ihmal ettiğinden, bizzat araştırmanın kendisini ve dolaysıyla da bulgularını ve sonuçlarını önemli ölçüde zayıflatmaktadır. Bu itibarla tüm tarihi, bir takım genel prensipler içine alma çabaları, tarihi gerçekleri açıklamaya engel olabilmektedir.

Yanlı tarih araştırmalarının sakıncalarına işaret eden bir tarihçi şu tespitte bulunur. "...Tarihin siyasi mücadelede bir silah olarak kullanılmasının ters sonuçlar verdiği kanısındayım. Insan zamanla kendi propagandasına inanmaya başlıyor, geçmişi aşırı ölçüde dramatikleştiriyor, sonuçta da her hangi bir dönemde geçmiş olayların gerçek karmaşıklığını unutuyor. Insan kendi taraf olduğu geçmişi idealize etmeye başllyor ve bu da insanları Biz ve Onlar şeklinde bölüyor" (Tosh:1997:22).

Togan, tarih araştırmalarında, izlenmesi gereken yöntemi özet olarak şöyle belirler: "Tarih araştırmast yapılırken tarih felsefesi ekollerinden hiç birine kapılmamal, her devir ve her vaka hakkinda bunlardan bir veya bir kaçının müessir olduğunu düşünerek çalışllmalıdır. Tarihi olaylarda en çok tabii ve iktisadi amillerin etkili olduğunu benimsemeli, ancak, ruhi amilleri de müstakil müessir amiller olarak tanımall. Tarih incelemelerinde tutulacak en iyi yol, tarih felsefeleri açısından bitaraf (tarafsız) kalarak, hadiselerin hangilerinde ne gibi amillerin etkili bulunduğunu, hiçbir ön yargıya tabi olmadan tespit etmeye çalışmalıdır" (Togan:1985:144-145).

\section{Tarih Araştırmaları Türleri}

Tarih araştırmalarında önemli bir sorun ise tarih araştırmalarının belirli guruplara ayrılarak incelenmesidir. Tarih araştırmalarını hikayeci (rivayetçi), ögretici (pragmatik) ve araştırıcı olmak üzere üç guruba ayıran Kütükoğlu hangi tür araştırma olursa olsun, ilmi tarihçilik yapılabilmesinin, incelenecek konu ya da olayın geliştiği coğrafi, sosyal, siyasi ve iktisadi koşulların dikkate alınmasına bağlı olduğunu vurgular (Kütükoğlu:1997:8).

Heredetos'un temsil ettiği rivayetçi (hikâyeci) tarih, vakayiname türü eserlerle İslam dünyasında da kullanılmış bir tarih türüdür. Bu yaklaşımla yazılan eserlerde olayların sebepleri ve sonuçları arasında ilişki kurulmamıştır. 
Geçmiş olaylardan ders almak, okuyucuya ahlaki ve milli duygular aşılayabilmek amacıyla yazılan eserler ise, öğretici özellikleri nedeniyle, ögretici veya pragmatik tarih akımına dahil edilmiştir. İslami kaynaklar arasında siyer kitapları adıyla anılan bu tür eserlerde, okuyucunun ilgisini çekmek ve duygusal bir etki yaratmak amacıyla daha çok zaferler ve parlak olaylar işlenmiştir.

Rivayetçi ve öğretici tarihten, kullandığı yöntem ve izlediği üslup bakımından oldukça farklı olan diğer bir tarih yazını ise özellikle 19. yüzyılda gelişen araştırıcı tarih anlayışıdır. Bu tür tarih yaklaşımda yaşanmış olayların ne rivayetçi tarihte olduğu gibi sadece yer ve zaman bildirerek aktarılması ve ne de yaşanmış olaylarda üstün görülen yanların tanıtılması söz konusudur. Olayların çıkış sebepleri, bunları hazırlayan amiller, farklı olayların birbirleriyle ilişkileri ve sonuçları arasında ilişkilendirmeye dayalı bir anlayış, araştırıcı tarih çalışmalarının özünü oluşturur.

Tarih araştırmaları, çıkış noktası itibariyle de iki guruba ayrılırlar. Birincisi Kaynak Yönelimli araştırmalardır ki, bu tür araştırmalarda birbirinden farklı verilerden oluşmuş bir yı̆̆ın belge üzerinde çalışılır ve araştırma süresince zamanının çoğu kaynak kritiğine ayrılır.

İkincisi Sorun Yönelimli yaklaşımdır ki, bu tür araştırmalarda hangi kaynakların konuyla ne derece ilişkili olduğunu önceden bilmek hiç de kolay değildir. Kimi zaman ilişkili olma ihtimali en uzak görünen kaynaklar çok aydınlatıcı olabilirken, konuyla ilişkili olduğu kabul edilenler tarihçiyi, bu kaynakları ortaya koymuş olan kurumun kaygılarıyla çok fazla özdeşleşmeye götürebilir.

\section{Tarih Araştırmalarında Sinırlama}

Herhangi bir tarihsel dönemdeki insan düşüncesi, faaliyet ve başarılarının tüm boyutları tarih araştırması konusu olabilir. Ancak tarih araştırmasının konusu, kabul edilebilir mantıklı gerekçelerle sınırlandırılmamışsa, gerek dönem olarak gerekse ele aldığı konu bakımından hepsinin birden araştırılması imkânsızlaşır. Bu açıdan bilimsel araştırmaların önemli bir niteliği olan sınırlandırma tarih araştırmaları için önemli bir gerekliliktir. Sınırlandırma, kaynakların belirlenmesi, ulaşılması ve kullanılması açısından olduğu kadar, araştırmanın tamamlanabilmesi bakımından da önem taşır.

Tarih araştırmalarında zaman sınırlaması sorunu, tarihçilerce tartışılan bir konudur. Tarih araştırmalarında uzun dönemleri kapsayacak araştırmaların birçok yararı olduğuna işaret edilmiştir. Tarihi seyrin iyi bir şekilde görülebilmesi bakımından uzun dönemleri kapsayan tarih çalışmaları salık verilir. Özellikle kurumlarla ilgili tarih araştırmalarının uzun dönemli olması gerekir. Şayet bir sınırlama yapılacaksa, konu açısından bir takım kabul edilebilir tarihi ve mantıki dönüm noktaları aranmalıdır. 


\section{Eğitim Tarihi Araştırmaları ve Yöntem}

Eğitim araştırmalarının gerçekleştirildiği dört araştırma türü söz konusudur. Bunlar betimsel (nitel), nedensel, genelleme ve temel (kuramsal) araştırmalardır. Betimsel araştırmanın iki önemli kolu vardır: bunlar Tarihsel ve çağdaş araştırmalardır. Betimsel araştırma ilk ve temel araştırma eylemidir. Bilginin anlaşılması ve araştırılmasında büyük önemi vardır (Balc1:1997:6).

Betimsel araştırmalar kısmında yer alan Eğitim Tarihi araştırmaları, genel tarih araştırmalarının amaç, işlev ve yöntemleriyle yakından ilişkilidir. Ancak eğitim tarihi araştırmalarında nasıl bir yöntem kullanılması gerektiği bu araştırmanın da üzerinde durduğu asıl metodolojik sorunu oluşturmaktadır. $\mathrm{Bu}$ sorun, eğitim tarihi araştırmalarının kendine özgü yapısından kaynaklanmaktadır. Bulunulan andan öncesine ait olan bir eğitim geçmişinin araştırılması, gerek kapsam olarak konunun genişliği, gerekse kaynaklarının çeşitliliği nedeniyle, araştırmanın dayanağını teşkil eden çok önemli iki temel sorundur. Zira yöntem, araştırmayı kurgulamada ve sonuçlandırmada yol gösterici bir araçtır. Bu araç kullanılmaksızın amacın gerçekleşmesi olanaksızdır.

Eğitim tarihi araştırmalarında, genel bir başlık altında toplanabilecek çeşitli yöntemler kullanılagelmiştir. Bu genel yöntemin adı nitel araştırma yöntemidir. Çeşitli disiplinlere dayanan ve güçlü kuramsal temelleri olan nitel araştırmalar, özellikle sosyoloji, antropoloji, psikoloji, felsefe ve dil bilimlerinde yaygın olarak kullanılan bir yöntemdir. Nitel araştırma yöntemini kullanan disiplinlerin ortak teması, insan davranışını, içerisinde bulunduğu ortam içinde ve çok yönlü olarak anlamaya çalışmaktır (Yıldırım ve Şimşek:1999:14).

Nitel araştırma, aslında bir şemsiye kavram olarak, çeşitli araştırma teknik ve modellerini içeren bir üst kavramdır. Birçok tanımı yapılan nitel araştırma, gözlem, görüşme ve doküman analizi gibi nitel veri toplama yöntemlerinin kullanıldiğı, algıların ve olayların doğal ortamda, gerçekçi ve bütüncül bir biçimde ortaya konmasina yönelik, nitel bir sürecin izlendiği araştırma olarak tanımlanabilir (Yıldırım ve Şimşek:1999:14).

Toplanan veriler 1şığında analizler yapmaya dayanan nitel araştırmada, üç tür veri toplanır. Bunlar, algılar, çevresel veriler ve süreçle ilgili verilerdîr. Nitel araştırmalar için gerekli olan bu üç tür veri, görüşme, gözlem ve yazılı dokümanların incelenmesi yoluyla elde edilir. Nitel araştırmalar için öngörülen veri toplama yöntemlerinin her biri kendi içinde alt guruplara ayrilır. 
Nitel araştırmaların temel farklılığı, araştırma sürecinde elde edilen verilerin nitel veriler olmasıdır. Bu tür veriler, nicel araştırmalarda olduğu gibi çoğu defa sayılara indirgenemez. Her ne kadar nitel yöntemlerle toplanan veriler üzerinde bazı sayısal analizler yapmak olanaklı ise de, nitel araştırmalarda temel amaç, sayılar yoluyla sonuçlara ulaşmak değil, okuyucuya araştırllan konuyla ilgili, betimsel ve gerçekçi bir resim sunmaktır.

Nitel araştırmalar, nicel araştırmalardan farklı olarak, araştırmanın süreci içerisinde, karşılaşılan yeni durumlara ve bulgulara göre yeniden biçimlendirilebilir. Süreç içerisindeki bu yeniden biçimlendirmenin derecesi, araştırmanın konusu ve çalışılan ortamın özelliği ile yakından ilgilidir. $\mathrm{Bu}$ yüzden nitel araştırmalarda sınırları açıkça belirlenmiş bir başlangıç noktasından hareketle izlenen ve araştırma sürecinde değişmeyen, belirli sabit aşamalar söz konusu değildir. Zira nitel araştırma doğası gereği, araştırma sürecinin çeşitli aşamaları arasındaki karşılıklı etkileşimi, esnekliği ve ilişkiyi ön plana çıkarmayı amaçlar (Maxwel; Yıldırım ve Şimşek:1999:14).

Katı bir izleme süreci olamamakla birlikte, nitel araştırmalar belirli aşamalar izlenerek yapılır. Nitel araştırmalarda izlenen belirli aşamalar şöyle sıralanabilir (Yıldırım ve Şimşek:1999:52-58):

- Araştırma probleminin belirlenmesi,

- Kuramsal / kavramsal çerçevenin oluşturulması,

- Araştırma sorusunun yazılması,

- Araştırma alanının / örneklemin belirlenmesi,

- Araştırmacinın rolünün belirlenmesi,

- Veri toplama araçlarının / stratejilerinin geliştirilmesi,

- Veri toplama (görüşme, gözlem ve belgelerin temini),

- Veri analizi, bulgularm betimlenmesi ve yorumlanmasi,

- Sonuçların sınırlanması ve genellenmesi,

- Araştırmanın kuram ve uygulama için doğurduğu sonuçların yazilmas1.

Nitel araştırmalarda, izlenmesi gereken bu aşamalardan her biri, kendi içerisinde çeşitli alt problemleri içerir. Burada tüm aşamaların, araştırma sürecinde, nasıl oluştuğuna değinilmeyecektir. Ancak, nitel bir araştırmanın yürütülmesinde araştırmacı için en fazla önemli olan örneklem seçimi, veri toplama tekniği ve veri analizi süreçleri üzerinde kısaca durulacaktır. 
a- Örneklem seçimi, tüm bilimsel araştırmalar için bir zorunluluktur. Araştırma evreninin kesin hatlarıyla belirlenmesi, araştırmacının bütün sorunlarını çözmez. Evren, çoğunlukla bir araştırmacının ulaşamayacağı kadar büyüktür. $\mathrm{Bu}$ sorunun çözümü için araştırmacılar, örneklem seçimine başvururlar. Örneklem alınmasındaki temel mantık, çok sayıda ve ulaşılması olanaksız birey, olay ve olguyu içeren evrenin, belirli yöntemlerle, evreni temsil edeceği varsayılan ve ulaşılması mümkün olan, temsili bir alana indirgenmesidir. $\mathrm{Bu}$ sayede, araştırmanın bütün evrenini çalışmak yerine, evreni temsil etme gücüne sahip, sinırlı sayıda birey, olay veya olgu araştırma kapsamına dâhil edilerek, pratik bir çözüm bulunmuş; çalış1labilir bir büyüklüğe indirgenmiş olur.

$b$ - Nitel araştırmalarda veri toplama yöntemleri, genel olarak görüşme, gözlem ve doküman incelemesi'nden ibarettir. Eğitim tarihi araştırmalarında da en fazla başvurulan doküman incelemesi, genellikle uzak geçmişe dair araştırma yapan tarihçilerin ve arkeologların, bir kültür veya medeniyetin geçmişine ilişkin özelliklerin belirlenmesi ve anlaşılmasına yönelik araştırmalarında kullanılır. Bu yöntemle araştırmacı, elde ettiği belgeleri belirli bir çerçevede ve birbiriyle ilişkilendirerek, ilgili kültür veya medeniyete ilişkin, bütüncül bir resim elde etmeye çalışır.

Doküman incelemesi yöntemi, geçmiş toplumlara ait kültürler, gelenekler, kurumlar, yaşantılar ve devlet politikalarına ilişkin bilgilerin elde edilmesi sürecinde işlevsel bir yere sahiptir. Doküman incelemesini kullanan tarihçiler ve arkeologlar, geçmiş hakkında bugün bildiğimiz şeylerinin pek çoğunu, bu yazılı kaynakların analizi yoluyla günümüze ulaştırmışlardır. Bu anlamda yazılı malzemeler, geçmiş hakkında bilinmeyen pek çok şeyi sunan, çok değerli bilgi kaynaklarıdır.

Nitel araştırmalarda, doğrudan gözlem ve görüşmenin olanaklı olmadığı durumlarda, araştırmanın problemiyle ilişkili yazılı ve görsel materyal ve malzemeler araştırmaya dahil edilir. Şu halde, doküman incelemesi veya analizi, tek başına bir araştırma yöntemi olabildiği gibi, diğer nitel yöntemlerin (görüşme veya gözlem) kullanıldığı durumlarda da, ek bilgi kaynağı olarak kullanılabilmektedir (Yıldırım ve Şimşek:1999:140).

Doküman incelemesi, araştırılması hedeflenen, olay veya olgular hakkında, bilgi içeren yazılı materyallerin analizini kapsar. Doküman incelemesi, geleneksel olarak, tarihçiler, antropologlar ve dil bilimcilerin kullandığı bir yöntem olmakla birlikte, sosyologlar ve psikologlar da doküman incelemesi kullanarak önemli kuramların geliştirilmesine katkıda bulunmuşlardır. 
1930'lu ve 1950'li yıllar arasında, doküman incelemesi, sosyal bilimlerde, yaygın olarak kullanılmıştır. Ancak 1960'lardan sonra, sosyal bilimlerdeki çalışma alanlarına pozitivist anlayışın egemen olması, bu yöntemin ihmal edilmesine neden olmuştur.

$\mathrm{Bu}$ yöntemin kullanılmasındaki temel sorun, hangi dokümanların önemli olduğu ve veri kaynağı olarak kullanılabileceği problemidir. Örneğin eğitim ile ilgili bir araştırmada, şu tür dokümanlar veri kaynağı olarak kullanılabilir. Eğitim alanında ders kitapları, program (müfredat) yönergeleri, okul içi ve dişı yazışmalar, öğrenci kayıtları, toplantı tutanakları, öğrenci rehberlik kayıt ve dosyaları, öğrenci ve öğretmen el kitapları, öğrenci ders ödevleri, ders ve ünite planları, eğitimle ilgili resmi belgeler vb. Araştırma alanına göre günlükler, özel mektuplar, itiraflar gibi kişisel bilgiler dışında yazılı basın, periyodik yazılı kaynaklar, magazin dergi ve kitapları da doküman analizine konu olabilirler.

Dokümanlar, nitel araştırmalarda, etkili bir şekilde kullanılması gereken önemli bilgi kaynaklarıdır. Doküman incelemesi, araştırmacıya belirli ölçüde zaman ve kaynak tasarrufu anlamında katkıda bulunur.

Doküman incelemesinin olumlu ve olumsuz yönlerine de işaret edilebilir. İnceleme yapılan alanda kaynağa kolaylıkla ulaşılamadığ durumlarda önemli bilgi toplama yöntemi olmas1, görüşme ve gözlem yönteminde karşılaşılan tepkiselliğin olmaması, uzun süreli araştırma yapma olanağ1 sunması, örneklerin büyük olarak alınabilmesi, dokümanların yazıldığı dönemdeki kişi ya da güçlerin bireysel ya da özgün tutumlarını yansıtması ve görece düşük maliyet gerektirmesi doküman incelemesinin olumlu yönleridir. Ancak başta dokümanlara ulaşma güçlüğü, elde edilen dokümanlarda bulunabilecek eksik bilgiler, olası yanlılıklar, bunların belirli bir gurup ya da kuruma ait seçilmiş dokümanlar olması, dokümanlardaki örneklerin yanlılığ 1 ve sözel olmayan davranışlar içermemesi, standart bir formata sahip olmaması ve kodlama zorlukları gibi, olumsuz yönleri de bulunmaktadır (Yıldırım ve Şimşek:1999:143-146).

Doküman İncelemesinin Aşamaları

Tarih araştırmalarında sıkça kullanılan dokümanların incelenmesi belirli aşamalarda gerçekleşir. Ancak, her araştırmacı için, araştırma probleminin niteliğine, doküman incelemesinde elde etmeyi hedeflediği veriye ve dokümanları hangi ölçüde kapsamlı ve derinlemesine incelemek isteğine bağlı olarak, bu aşamalar yeniden yorumlanabilir. Doküman incelemesinde genellikle şu işlemler yapılır:

- Dokümana ulaşma,

- Dokümanların orijinalliğinin kontrol edilmesi,

- Dokümanların incelenmesi ve anlaşılması,

- Dokümanlardaki verilerin analiz edilmesi,

- Verilerin kullanılması. 
c- Veri analizi, nitel araştırmanın son ve en fazla güçlük çekilen aşamalarından biridir. Veri toplama aşamasında çıkabilecek olası güçlükler, araştırmacı tarafından belirlenen bir veri seti hazırlamak ve bunlara ulaşmakla giderilebilir. Ancak toplanan verilerin, araştırmanın özünü oluşturan veri analizi ve raporlaştırma aşamalarında güçlükler çıkabilir. Doküman incelemesine dayalı her araştırma, gerek kaynakları ve gerekse kaynakların içerikleri bakımından, farklı özellikler taşır ve benzeri diğer araştırmalarda kullanılan veri analiz yöntemleri aynen kullanılamaz. Doküman incelemesine dayalı her araştırma, veri analiz aşamasında, bir takım yeni yaklaşımlar gerektirir. $\mathrm{Bu}$ nedenle araştırmacının, kendi araştırmasına esas olacak bir veri analiz planı geliştirmesi zorunludur.

Genel olarak, veri analizinde, şu sürecin izlenmesi önerilir:

Betimleme: Araştırmada toplanan verilerin, araştırma problemine ilişkin olarak neler söylediği, ya da hangi sonuçları ortaya koyduğunun saptanması. Bu bağlamda, elde edilen dokümanların, araştırma konusuyla ilgili ne tür bilgiler ortaya koyduğu üzerinde durulur.

Analiz: Araştırma için oluşturulan veri setinde, doğrudan görülmeyen ancak, kavramsal siniflama ve kodlama yoluyla, temaların ve bu temalar arası anlamlı ilişkilerin ortaya çıkarılması sürecidir.

Yorumlama: Araştırmanın veri seti üzerindeki çalışmalar sonucunda, elde edilen bilgilerin ne anlama geldiği sorusunun, araştırmacı tarafindan yanıtlanmasıdır. Veri analizinde "anlam" ön plana çıkmaktadır. Anlamın ön plana çıkması ise, betimleme ve analizi aşan ileri bir aşamadır. Bu süreçte elde edilen bulgular ilişkisel biçimde yorumlanır. Verilerin anlamlandırılması, aynı zamanda, öznel bir süreçtir ve bu nedenle yorumların mutlak nesnelliği iddia edilemez.

Görüldügü gibi nitel verilerin analizi konusunda farklı kavram ve yaklaşımlar bulunmaktadır. Ancak bu farklı yaklaşımların üzerinde uzlaştığ konu verilerin betimlenmesi ve temaların ortaya çıkarılmasına verilen önemdir. Bununla birlikte, araştırmacının yorumları ve ortaya çıkan temaların anlamlı bir biçimde ilişkilendirilmesi nitel araştırmaların diğer ortak yönünü oluşturmaktadır.

Literatürde yer alan farklı veri analiz türlerine rağmen, yapılan analizin derinliğine göre, veri analizini başlıca iki gurupta ele almak mümkündür.

\section{1-Betimsel Analiz}

$\mathrm{Bu}$ yaklaşımında, elde edilen veriler, daha önceden belirlenen temalara göre özetlenir ve yorumlanır. Veriler, araştırma sorularının ortaya koyduğu 
temalara göre organize edilebileceği gibi, görüşme ve gözlem süreçlerinde kullanılan sorular ya da boyutlar dikkate alınarak da sunulabilir. Betimsel analizde, anlatılara sık sık yer verilir. Bu tür bir analizde amaç, elde edilen bulguları düzenlenmiş ve yorumlanmış bir biçimde okuyucuya sunmaktır.

Betimsel analizde önce, elde edilen veriler mantıklı ve anlaşılır bir biçimde betimlenir. Daha sonra, yapılan bu betimlemeler yorumlanır, neden sonuç ilişkileri incelenir ve bir takım sonuçlara ulaşılır. Ortaya çıkan temaların ilişkilendirilmesi, anlamlandırılması ve ileriye yönelik tahminlerde bulunulması işlemleri de, araştırmacının yapacağı yorumlar arasında yer alabilir.

Betimsel Analiz dört aşamadan oluşur:

1- Betimsel Analiz İçin Bir Çerçeve Oluşturma: Araştırma sorularından ve araştırmanın kavramsal çerçevesinden yola çıkılarak, veri analizine esas teşkil edecek bir çerçeve oluşturulur. Bu çerçevede, verilerin hangi temalar altında organize edilec eği ve sunulacağ

2- Tematik Çerçeveye Göre Verilerin İşlenmesi: İlk aşamada oluşturulan tematik çerçeveye göre, elde edilen veriler okunur ve organize edilir. $\mathrm{Bu}$ aşamada, verilerin, tanımlanma amacıyla seçilmesi, anlamlı ve mantıklı bir biçimde bir araya getirilmesi söz konusudur.

3- Bulguların Tanımlanması: Organize edilen veriler tanımlanır ve gerekli yerlerde metin içinden doğrudan alıntılarla desteklenir.

4- Bulguların Yorumlanması: Betimsel analizin son aşaması olan bu safhada tanımlanan bulguların açıklanması ve anlamlandırılması yapılır. Bulgular arasında, neden sonuç ilişkilerinin açıklanması ve gerekirse farklı olgular arasında karşılaştırma yapılması yoluna gidilebilir.

\section{2- İçerik Analizi}

İçerik analizi, nitel araştırmalarda önemli bir veri analiz yöntemidir. İçerik analizinde temel amaç, toplanan verileri açıklayabilecek kavramlara ve ilişkilere ulaşmaktır. Betimsel analizde özetlenen ve yorumlanan veriler, içerik analizinde, daha derin bir işleme tabi tutulur ve betimsel yaklaşımla fark edilmeyen kavram ve temalar içerik analiziyle keşfedilebilir. Bu amaçla toplanan verilerin, önce kavramsallaştırılması, daha sonra da ortaya çıkan kavramlara göre mantıklı bir biçimde organize edilmesi ve buna göre veriyi açıklayan temaların saptanması gerekmektedir.

Buraya kadar anlatılanlar genelde sosyal bilimlerde ve özellikle de tarih araştırmalarında kullanılan nitel araştırma yöntemlerine ilişkin bilgilerdi. Eğitim tarihi araştırmaları da bu genel tarih araştırma metodundan olabildiğince yararlanır. Yukarıda anlatılan yönteme ilişkin tespitlerin eğitim tarihi araştırmaları için de geçerli olduğunu söyleyebiliriz. 


\section{Eğitim Tarihi Araştırmaları ve Temel Kaynakları}

Eğitim tarihi genel anlamıla bir milletin öğretim ve eğitiminin tarihi biçiminde tanımlanabilir. Başka bir ifadeyle eğitim tarihi genel tarih içerisinde yer alan, eğitim ile ilgili bir Tarih bilimidir (Akyüz:2007:1). Hayat boyu süren öğretim ve eğitim, insanın ve toplumun olduğu her yerde var olduğuna göre eğitim tarihi, insanlık tarihi kadar eskidir. Şu halde, yeryüzünün her hangi bir coğrafyasında yaşamış bütün toplumlar ve uluslar için mutlaka bir eğitim tarihi geçmişinden söz etmek gerekir.

Eğitim tarihi araştırmaları, bilimsel araştırma yöntemlerine dayalı olarak yürütülür. Ancak eğitim tarihi, kendine özgü yöntemler kullanan bağımsız bir bilim dalı olmadığından, bu tür araştırmalar yürütülürken, ilişkili olduğu bilim dallarınca elde edilen bilgiler ve kullandıkları yöntemlerden yararlanma yoluna gidilir. Disiplinler arası (interdisipliner) bir bilim dalı olan eğitim, kendi tarihine ilişkin araştırmalarda da diğer bilimlerden mutlaka yararlanır. Bu itibarla eğitim tarihi araştırmaları, eğitim bilimiyle ilişkisi olan temel bilim dalları yardımıyla yürütülür. Eğitim bilimi, öncelikle felsefe, sosyoloji ve psikoloji gibi sosyal bilimlerle doğrudan ilişkilidir. İster bugünle, ister geçmişle ilgili olsun, eğitim üzerine yapılacak araştırmalar, bu bilimlerin bir ya da birkaçından bağımsız olarak yürütülemez.

Eğitim tarihi araştırmaları, temelde tarih disiplini içerisinde kalmakla birlikte, bir çok bilim dalıyla ilişki içerisinde yürütülür. Eğitim tarihi araştırmaları ele aldığı dönem, sistem, kurum, olay ve şahıslar hakkında çeşitli sorular yöneltir. Tosh'un deyimiyle soru sormak, felsefenin toprağına adım atmak demektir (Tosh:1997:122). Öte yandan felsefe, dünya görüşlerinin kavranmasına aracılık edecek en yararlı bilimdir. Tarihsel olayların tahlili de ancak kapsamlı felsefi düşünüşle yapılabilir. Felsefenin eleştirel üslubu, tarihsel gerçekliğin anlaşılmasında önemli rol oynar. Toplumsal yönü ağırlıklı olan eğitim tarihi araştırmalarında, felsefe anlama çabası için önemli bir destek sunar. Şu halde eğitim tarihi araştırmaları felsefeden uzak bir yaklaşımla yürütülemez.

Eğitim tarihi araştırmaları yaşanmış insan faaliyetlerini ele alır. Doğrudan insan davranışıyla şekillenen eğitimin tarihsel olarak anlaşılması, ancak insan davranışları nazariyeleriyle mümkün olabilir. Şu halde psikoloji eğitim tarihi araştırmalarında başvurulacak bir diğer önemli yardımcı bilimdir. Zira psikoloji sayesinde insanın mahiyeti, karakteri ve davranışına açılık getirilebilir. 
Öte yandan eğitim tarihi toplumsal yaşantının tarihidir. Toplumun oluşması, toplumsal davranış, toplumsal değişim, toplumsal olaylar, toplumsal olgu ve toplumsal sinıflar hakkında bilgi sahibi olmadan, kendisi de bir toplumsal faaliyet olan eğitimin anlașılması güçtür. Bu itibarla toplumbilim (sosyoloji) eğitim tarihi araştırmalarında en sık başvurulacak bilimlerdendir.

Eğitim tarihi, öğretim ve eğitim düşüncesinin, kurumlarının, olaylarının, deneyimlerinin ve uygulamalarının tümünü kapsar. Eğitim tarihinin kapsamını eğitim ve öğretim terimlerinin kapsamıyla açıklayan Akyüz, Türk Eğitim tarihinin kapsamına bu iki boyut açısından da açıklık getirir. Akyüz'e göre Türk Eğitim tarihinin eğitim boyutu açısından kapsadığı alanlar şunlardır (Akyüz:2007:2):

Halk ve yetişkinler eğitimi, yaygın eğitim kurumları, Kitle iletişim araçları ve etkileri, toplumun çocuk yetiştirme yöntemleri ve çocuk oyunları, toplumda yaygın biçimde ortaya çıkan eğitim düşüncesi ve uygulamaları, toplumun eğitim ve bilim anlayışı, eğitim değerleri, atasözleri, destanlar, masallar, ninniler, büyük edipler, ahlakçılar, siyasetnameler vb.

Akyüz, öğretim boyutu açısından ise Türk eğitim tarihinin kapsamını şöyle açıklar (Akyüz.2007:2):

Okullar, ders program ve kitapları, devletlerin, rejim ve hükümetlerin eğitim amaçları, eğitim felsefeleri, eğitim ve ögretmen sorunları, okul, öğretmen ve öğrencilere ilişkin sayısal bilgiler, eğitimle ilgili yasal belgeler, devlet adamlarının söylev ve demeçleri, eğitim sisteminin yapısı, işlevi, eğitim düzenleme ve sslah çalışmaları, eğitimci ve öğretmenlerin anı, görüş ve düşünceleri, eğitimcilerin ve aydınların tartıştığı, geliştirdiği eğitim düşüncesi, okul ve öğretmenlerin toplumdaki yeri ve etkisi vb.

Genel tarih araştırmalarının bir alt dalı olan eğitim tarihi araştırmaları, gerek yöntem, gerekse kaynakları bakımından genel tarih araştırmalarıyla benzerlikler gösterir. Kapsamı oldukça geniş tutulan eğitim tarihi araştırmaları, kaynakları bakımından da oldukça zengindir.

Yukarıda değinildiği gibi tarih araştırmalarında kaynak sorunu, tarih disiplini açısından en önemli problematiği oluşturur. Kaynak sorunu gerek araştırmanın yürütülmesi sürecinde, gerekse araştırmanın güvenli sonuçlar vermesi bakımından eğitim tarihi araştırmaları için hayati derecede öneme sahiptir. Çünkü araştırmada kullanılacak kaynaklar araştırmanın inşasında belirleyici rol oynamaktadır. 
Tarih araştırmalarında kullanılan kaynaklar, taşıdıkları önem derecesine göre sınıflandırılırlar. Taşıdıkları önem dikkate alındığında tarihsel kaynakları birincil ve ikincil kaynaklar olarak iki kısma ayırmak yararlıdır. Birincil kaynaklar, araştırmanın ele alındığ 1 dönem, ulus, olay, kurum, uygulama ve kişilerle aynı döneme ait resmi belgeleri ifade eder. ${ }^{1}$ Bunlar aynı zamanda özgün (orijinal) kaynaklardır. Bir kaynağın resmiyeti ve incelenen konuyla aynı dönemde üretilmesi, onun birincil kaynak olup olmamasını önemli ölçüde belirler. Ancak bazı titiz tarihçiler, birincil kaynakları, o dönemde üretilseler bile, görgü tanıklığına dayanmayan ifadeleri de dikkate alarak, görece birincil kaynak kabul etme taraftarıdırlar (Tosh:1997:34).

Tarihçilerin kendilerinin ve kendilerinden öncekilerin geçmişle ilgili olarak ortaya koyduğu ürünler ise ikincil kaynaklar olarak nitelendirilir. İkincil kaynakların yararları asla inkâr edilemez. Genellikle ikincil muteber kaynaklar yardımıyla özgül bir tarihsel sorun formüle edilip sonra bununla ilgili birincil kaynaklar incelenmeye başlanır.

Oldukça zengin bir çeşitliliğiyle sahiptir. Bu kapsamda yazılı ve sözlü dil, coğrafi yüzey şekillerinin durumu ve insan yapımı maddi kalıntılar, güzel sanatlar, fotoğraf ve filmler bu zengin kaynakları oluşturur. Kütükoğlu tarih araştırmalarının temel kaynaklarını üç guruba ayırır (Kütükoğlu:1998:18-28):

1- Sözlü Kaynaklar. Tarihi şiirler, hikâyeler, efsaneler, mitler, destanlar, menkıbeler, fikralar ve atasözleri.

2- Yazıll, çizili, sesli ve görüntülü kaynaklar. Bunlar ise üç gurupta toplanir.

a-Arşiv malzemeleri: Yazılı arşiv malzemeleri, çizili arşiv malzemeleri, görüntülü ve sesli arşiv malzemeleri.

b-Kütüphane malzemeleri: Şecereler, takvimler ve yıllıklar, vakayinameler, biyografiler, otobiyografiler, hatıralar, seyahatnameler, süreli yayınlar.

c-Müzelik Malzemeler: Kitabe, abide, heykel, lahit, mezar taşları, madalyalar, insan vücudu bakiyeleri, örf ve adetlere ait maddi kalıntılar, dil, paralar, armalar ve mühürler.

\footnotetext{
${ }^{1}$ Bazen bir kaynaktan birincil kaynak olarak söz edilmesi o kaynağın güvenilirliğine ya da tarafsızlığına ilişkin değerlendirme yapma imkânı vermeyebilir. Hatta birincil kaynakların pek çoğu kesinlikten uzak, muğlâk, kulaktan dolma ya da yanıltma amacı güden kaynaklar da olabilir. Tarihçinin çalışmasının asıl önemi bu tür tahrifatları ortaya çıkarmasında yatar.
} 


\section{Eğitim Tarihi Araștırmalarının Kaynakları}

Eğitim tarihi araştırmalarının kaynakları, eğitim tarihi kapsamının genişliğine paralel olarak, oldukça çeşitli ve zengindir. Eğitim tarihi araştırmalarında kullanılan temel kaynaklar öncelikle ilgili dönemin genel ve mesleki basin organları, meclis tutanaklarl, arşiv kaylt ve belgelerinden oluşmaktadır. Bunların yanında ĕgitimcilerin anıları, gerek makale, gerekse kitap tarzında yaşlı ve genç eğitimcilerin derleme ve değerlendirmeleri de vazgeçilmez diğer kaynaklardır (Ergün:1997:9).

Birçok eğitim tarihi araştırmasında, yukarıda sayılan ve sayılmayan çeşitli kaynaklar kullanılmıştır. Şimdiye kadar yapılan araştırmalarda kullanılan kaynaklar dikkate alındığında, eğitim tarihi kaynaklarını başlıca iki ana gurupta toplamak mümkündür.

1- Resmi Kaynaklar: Eğitim tarihi araştırmalarında kullanılan en temel ve ilk akla gelen birincil kaynaklar resmi kaynaklardır. Resmi kaynaklar devletlerin düzenleme ve uygulamalarını ifade eden temel vesikalardır. Eğitim tarihi araştırmaları için birincil öneme sahip bu kaynaklar, devletlerin veya devlet kurumlarının eğitime ilişkin her türlü düşünce, planlama, düzenleme, uygulama, reform, istatistik ve raporlarını içerir. Oldukça çeşitlilik arz eden ve eğitim tarihi çalışmalarında vazgeçilmez bir yeri bulunan bu temel kaynakları kısaca arşiv vesikaları olarak nitelendirebiliriz. Arşiv vesikaları daha çok Osmanlı Dönemi ile Cumhuriyet Dönemine ait önemli karar ve düzenlemeleri içeren, resmi nitelikteki orijinal belgelerdir. Birincil kaynaklar olarak da anılan bu belgeler, Iradeler (Padişaha, çeșitli Nezaretler ve Meclis-i Mahsusa'ya ait ferman veya buyruklar), Nizamnameler (eğitim konularını düzenleyen genel hükümler), Mekatip Dosyaları, Salnameler (Maarif-i Umumiye, Devlet-i Aliye-i Osmaniye ve Vilayet y1llıklar1), Düsturlar, Kalkınma Planlarl, Hükümet Programları, Devlet başkanlarının, başbakanların ve eğitim bakanlarının resmi demeçleri, Anayasalar, Kanunlar, Ĕ̆itim Mevzuatı (yönetmelik ve genelgeler), Istatistikler, Şura Raporları, Ders programları ve Ders Kitapları'indan oluşmaktadır.

2- Diğer Kaynaklar: Resmi kaynaklar dışında kalan ikincil kaynaklardır. $\mathrm{Bu}$ tür kaynaklar, resmi düzenlemeleri ve uygulamaları içermeseler bile, eğitime ilişskin her türlü düşünce, uygulama ve sorunları ifade eden çok zengin belgelerdir. Resmi düzenlemelerin daha ayrıntılı biçimde anlaşılmasında yardımcı olan, resmi kaynaklara yansımamış önemli gelişme, sorun ve tartışmalar içeren bu tür kaynaklar, yazılı ve sözlü kaynaklardan oluşurlar. 
- Yazılı kaynaklar: Eğitim tarihine ilişkin yapılmış güvenilir araştırmalar, hatırat (anılar), biyografiler (otobiyografiler veya monografiler), süreli yayınlar (gazete ve dergiler), hükümet programları, yardımcı ders kitapları, özel yıllıklar, makaleler, anketler, özel istatistikler, panel, sempozyum ve konferans dokümanları, nasihatnameler vd.

- Sözlü kaynaklar ise atasözleri, hikayeler, masallar, destanlar, şiirler, mitler, menkıbeler, darb-1 meseller, sözlü anlatımlar (sözlü tarih araştırmaları temel kaynakları) dan oluşmaktadır.

\section{SONUÇ}

Sosyal bilim araştırmalarının bir türü olan ve eğitim bilimi araştırmaları içersinde yer alan Eğitim Tarihi, ilgili olduğu disiplinlerden geniş ölçüde yararlanarak bilgi üreten interdisipliner bir araştırma alanıdır. Eğitim tarihi araştırmalarında çoğunlukla Tarih araştırmalarının yöntem ve teknikleri kullanılır. Eğitim tarihi araştırmalarının en çok kullandığı araştırma teknikleri arasında nitel araştırma teknikleri yer alır. Nitel araştırmalar çoğunlukla gözlem, görüşme ve doküman analizi gibi nitel veri toplama yöntemlerinin kullanıldiğı, algiların ve olayların doğal ortamda, gerçekçi ve bütüncül bir biçimde ortaya konmasına yönelik, nitel bir sürecin izlendiği araş̧ırmalar olarak tanımlanabilir. $\mathrm{Bu}$ çerçevede nitel araştırmalarda geçmişe ait bilgilerin belirli bir yöntem disiplini içersinde elde edilmesi söz konusudur.

Eğitim tarihi araştırmalarını bir diğer temel sorunsalı araştırma kaynaklarıdır. Kapsamının genişliğine paralel olarak, oldukça çeşitli ve zengin olan Eğitim Tarihi araştırmalarının temel kaynakları tarih araştırmalarında kullanılan kaynaklarla benzerlik gösterir. $\mathrm{Bu}$ anlamda eğitim tarihi araştırmaları için resmi ve resmi olmayan diğer kaynaklar olmak üzere iki önemli kaynak grubu söz konusudur. Resmi kaynaklar birincil kaynaklar olarak da nitelendirilen arşiv vesikaları'dır. Bunlar eğitim tarihi araştırmalarında en sık başvurulan kaynaklar arasında yer alır. Ancak yeterli bilgiye ulaşamama ya da çarpitılma söz konusu olduğunda resmi kaynaklar yerine ikincil kaynak olarak nitelendirilen ve resmi olmayan diğer kaynaklar temel başvuru kaynağı olarak kullanılırlar. Bu kaynaklar resmi düzenlemeleri ve uygulamaları içermeseler de, eğitime ilişkin düşünceleri, uygulamaları ve sorunları dile getiren zengin bilgi kaynaklarıdır.

$\mathrm{Bu}$ değerlendirme 1şı̆̆ında, eğitim tarihi araştırması yapacakların bilimsel araştırma yöntemlerini dikkate alarak, mümkün olan en doğru bilgiye ulaştıracak temel kaynaklara başvurmaları kaçınılmaz bir gerekliliktir. 
KAYNAKÇA

Anderson, Gary. (1990). Fundamentals of Educational Research. London et al.: The Farmer Pres.

Akyüz, Yahya. (2007), Türk Ĕgitim Tarihi (M.Ö.1000-M.S.2007), İstanbul.

Balc1, Ali. (1997), Sosyal Bilimlerde Araştırma, Ankara.

Ergün, Mustafa. (1997), Atatürk Devri Eğitimi, Ankara.

Kütükoğlu, Mübahat. (1998), Tarih Araştırmalarında Usul, İstanbul.

Tosh, John. (1997), (Çev. Özden Arıkan), Tarihin Peşinde, İstanbul.

Togan, Z. Velidi (1985), Tarihte Usul, İstanbul.

Yıldırım, Ali. ve Şimşek, Hasan. (1999), Sosyal Bilimlerde Nitel Araştırma Yöntemleri, Ankara. 
